\title{
Peroxiredoxin III protects pancreatic $\beta$ cells from apoptosis
}

\author{
Gabriele Wolf*, Nicole Aumann"1, Marta Michalska, Antje Bast, Jürgen Sonnemann², James F Beck², \\ Uwe Lendeckel, Philip Newsholme ${ }^{3}$ and Reinhard Walther
}

\author{
Department of Medical Biochemistry and Molecular Biology, University of Greifswald, Klinikum, Sauerbruchstrasse, D-17487 Greifswald, Germany \\ ${ }^{1}$ Institute of Community Medicine, University of Greifswald, D-17487 Greifswald, Germany \\ ${ }^{2}$ Department of Pediatric Hematology and Oncology, University Children's Hospital Jena, D-07745 Jena, Germany \\ ${ }^{3}$ UCD School of Biomolecular and Biomedical Science, Conway Institute and Health Sciences Complex, UCD Dublin, Belfield, Dublin 4, Ireland \\ (Correspondence should be addressed to R Walther; Email: rwalther@uni-greifswald.de)
}

*(G Wolf and N Aumann contributed equally to this work)

\begin{abstract}
Type 1 diabetes mellitus is characterized by a progressive autoimmune destruction of insulin-producing $\beta$ cells. Macrophages and $\mathrm{T}$ lymphocytes release cytokines, which induce the synthesis of oxygen and nitrogen radicals in the pancreatic islets. The resulting cellular and mitochondrial damage promotes $\beta$ cell death. $\beta$ cells are very sensitive to the autoimmune free radical-dependent attack due to their low content of antioxidant enzymes such as glutathione peroxidase and catalase. A focal point of $\beta$ cell protection should be the control of the mitochondrial redox status, which will result in the preservation of metabolic stimulus-secretion coupling. For this reason, there is a considerable interest in the mitochondrial peroxiredoxin III (PRX III), a thioredoxindependent peroxide reductase, which was shown to be able to protect against both oxidative and nitrosative stress.
\end{abstract}

Using the Tet-On-system, we generated stably transfected rat insulinoma cells over- or under-expressing PRX III in a doxycyclin-dependent manner to analyze the effect of increased or decreased amounts of cellular PRX III, following treatment with several stressors. We provide evidence that PRX III protects pancreatic $\beta$ cells from cell stress induced by accumulation of hydrogen peroxide, or the induction of inducible nitric oxide synthase or caspase- 9 and -3 by pro-inflammatory cytokines or streptozotocin. Basal insulin secretion was markedly decreased in cells expressing lower levels of PRX III. We suggest PRX III may be a suitable target for promoting deceleration or even prevention of stress-associated apoptosis in pancreatic $\beta$ cells and the manifestation of insulin-dependent diabetes mellitus.

Journal of Endocrinology (2010) 207, 163-175

\section{Introduction}

Autoimmune destruction of pancreatic $\beta$ cells during the development of type 1 diabetes is a complex process involving both cellular and humoral elements of cytotoxicity (Mandrup-Poulsen et al. 1990). It is characterized by insulitis, an infiltration of pancreatic islets with lymphocytes, macrophages and neutrophil granulocytes releasing various pro-inflammatory cytokines (Eizirik \& Mandrup-Poulsen 2001). Chronic exposure to cytokines such as tumour necrosis factor- $\alpha$ (TNF- $\alpha$ ), interleukin $1 \beta$ (IL1 $\beta$ ), and interferon- $\gamma(\mathrm{INF}-\gamma)$ induces the synthesis of reactive oxygen species (ROS) and nitrogen species (RNS) via inducible nitric oxide synthase (iNOS; Rabinovitch \& Suarez-Pinzon 1998, Storling et al. 2005), which inhibit insulin secretion (Kiely et al. 2007). Oxygen free radicals, such as $\mathrm{O}_{2}^{--}$, and nitrogen free radicals, such as $\mathrm{NO}^{\circ}$, may act separately or interact to generate peroxynitrite (e.g. $\mathrm{O}_{2}^{--}+\mathrm{NO}^{-} \rightarrow \mathrm{ONOO}^{\circ}$ ), which is a powerful oxidant. These radicals can inactivate mitochondrial and cytosolic proteins, leading to a decrease in oxidative phosphorylation, decreased glycolysis, and consequently decreased ATP levels as well as impaired insulin secretion. The resulting mitochondrial damage promotes $\beta$ cell death (Azevedo-Martins et al. 2003), which in vivo will be followed by the manifestation of insulin-dependent diabetes mellitus (IDDM, also known as type 1 diabetes). Antioxidant enzymes such as glutathione-dependent peroxidase (Gpx) and catalase (Cat) are able to inactivate ROS and prevent oxidative stress (Radi et al. 1991, Knopp et al. 1999). The insulinproducing $\beta$ cells are very sensitive against autoimmune attack due to their low content of these antioxidant enzymes (Lenzen et al. 1996, Tiedge et al. 1997). Several groups have attempted to prevent $\beta$ cell destruction by over-expression of Cat, Gpx, mitochondrial Mn Superoxide dismutase (SOD), cytoplasmic $\mathrm{Cu} / \mathrm{ZnSOD}$, or thioredoxin with mixed results (Hotta et al. 1998, Bernabe et al. 2001, Sandström et al. 2002, Azevedo-Martins et al. 2003, Gurgul et al. 2004, Li et al. 2006, Harmon et al. 2009, Michalska et al. 2010). In animal models, 
scavengers of ROS and RNS have been shown to prevent $\beta$ cell death induced by the diabetogenic drug streptozotocin (STZ) or by the pro-inflammatory cytokines. In vivo, over-expression of $\mathrm{Cu} / \mathrm{ZnSOD}$ in diabetic animals provides protection against the development of alloxan- or STZ-induced diabetes. Moreover, addition of scavenging agents such as SOD, Catalase (Cat), guanidinoethyldisulphide, and metal chelators prior to alloxan, STZ, or cytokine exposure has prevented $\beta$ cell death in isolated islets (Gandy et al. 1982, Abdel-Rahman et al. 1992, Suarez-Pinzon et al. 2001). Lower concentrations of $\mathrm{H}_{2} \mathrm{O}_{2}$, however, seem to be involved in the regulation of physiological processes, e.g. receptor-mediated cell signaling pathways, cell proliferation, and transcriptional activation (Pi et al. 2007).

We have focused our work on the role of peroxiredoxins (PRXs) in protection from oxidative stress. In contrast to other antioxidant enzymes, insulin-producing cells are not compromised with respect to PRXs. PRXs comprise a family of highly conserved thioredoxin-dependent peroxide reductases (Chae et al. 1999, Kang et al. 2005), the only inducible antioxidant enzymes, which are known to protect against both oxidative and nitrosative stress (Hattori et al. 2003). PRXs are small proteins, which are able to form homo- and heterodimers as well as oligomers. They possess a highly conserved N-terminal Cys-residue. This sulfhydryl group enables the peroxidase activity, which results in disulfide bond formation, intramolecular or between two PRXs, and is followed by regeneration via thioredoxin. The function of mammalian PRXs is linked to the modulation of cytokine-induced $\mathrm{H}_{2} \mathrm{O}_{2}$ levels, which have been shown to mediate signaling cascades leading to cell proliferation, differentiation, and apoptosis. In addition, they play an important role in peroxide detoxification in cells in cooperation with glutathione peroxidases and catalases (Wood et al. 2003).

A focal point of $\beta$ cell protection should be the control of the mitochondrial redox status. For this reason, there is a considerable interest in PRX III, which is localized in the mitochondria and uses the mitochondrial thioredoxin-2 as electron donor (Watabe et al. 1997, Araki et al. 1999). Numerous synonyms, such as AOP-1 for antioxidant protein 1 (Mitsumoto et al. 2001), mer5 because it was originally isolated from murine erythroleukemia cells (Yamamoto et al. 1989), or SP-22 as substrate protein for mitochondrial ATPdependent protease (Lee et al. 2007), have been used to describe this multifunctional enzyme. Prx III can be induced by various stimuli (Araki et al. 1999, Nonn et al. 2003, Lee et al. 2007). It is able to regulate the physiological $\mathrm{H}_{2} \mathrm{O}_{2}$ concentration within the cells and to prevent apoptosis (Nonn et al. 2003). Chang et al. (2004) postulated that PRX III protects cardiolipin from lipid peroxidation. Cardiolipin is an anionic phospholipid, which binds cytochrome $c$ on the inner mitochondrial membrane. If cardiolipin is peroxidized by $\cdot \mathrm{OH}$, cytochrome $c$ is released from mitochondria to the cytosol, followed by the activation of specific caspases leading to apoptotic cell death (Petrosillo et al. 2003). We suggest that
PRX III could be a useful target to prevent cell death induced by oxidative stress and thus could prevent or at least delay the onset of the clinical symptoms of type 1 diabetes. To investigate whether this enzyme is able to protect insulinproducing cells against inflammatory stimuli while maintaining the functionality of these cells, we generated and analyzed stably transfected rat insulinoma cells (RINm5F) over- or under-expressing $\operatorname{Prx}$ III in a doxycyclin-dependent manner, using the Tet-On-system, which we have previously demonstrated to be important for analysis of the functional role of Pdx-1 (Lottmann et al. 2001).

\section{Materials and Methods}

\section{Animals and materials}

C57/BL6 mice used for islet preparation were purchased from the Department of Pathophysiology of the Greifswald University (Greifswald, Germany). Rat insulinoma cells RINm5F were a kind gift from Sigurd Lenzen from the Medical School Hannover. Mouse insulinoma cells $\beta$ TC6-F7 were from Shimon Efrat (Tel Aviv, Israel). Collagenase type IV and mouse antibody against glucagon or monoclonal rabbit antibody against iNOS were obtained from Sigma-Aldrich. Monoclonal mouse antibody against insulin was obtained from Chemicon (Ternecula, CA, USA). The rabbit polyclonal antibody directed against GAPDH was purchased from Abcam (Cambridge, UK). A rabbit polyclonal antibody directed against PRX III from rat or mouse was generated by SeqLab (Göttingen, Germany). Monoclonal rabbit antibody against cleaved poly (ADP-ribose) polymerase (PARP) was purchased from Cell Signaling (Danvers, MA, USA). The secondary antibodies anti-mouse-Cy2 and anti-rabbit-Cy3 were obtained from Dianova (Hamburg, Germany). Taq polymerase was from GE Healthcare (Munich, Germany). Cytokines were obtained from Roche. STZ was from Calbiochem Novabiochem (Nottingham, UK), and alloxan was from ICN (Northeim, Germany). Doxycyclin was purchased from BD Biosciences (Heidelberg, Germany). Geniticin G418 was obtained from PAA (Pasching, Austria). All other chemicals were from commercially available sources.

\section{Immunohistochemistry}

Paraffin slices of pancreas from Balb/c mice were successively incubated for $5 \mathrm{~min}$ in xylol, 100\% (v/v), 95\% (v/v), and 75\% $(\mathrm{v} / \mathrm{v})$ ethanol, double distilled water and $30 \mathrm{~min}$ in immunofluorescence buffer $(0 \cdot 2 \%(\mathrm{w} / \mathrm{v}) \mathrm{BSA}, 0 \cdot 05 \%(\mathrm{w} / \mathrm{v})$ saponin, $0 \cdot 1 \%(\mathrm{w} / \mathrm{v})$ sodium azide in PBS, $\mathrm{pH} 7 \cdot 4)$ followed by an overnight incubation at $4{ }^{\circ} \mathrm{C}$ with polyclonal rabbit anti-PRX III and monoclonal mouse anti-glucagon or anti-insulin antibody diluted 400 -fold in IF buffer. After washing with IF buffer, the immunoreacted primary antibodies were visualized with red fluorescent Cy3-conjugated goat anti-rabbit $\operatorname{IgG}$ and green fluorescent Cy2-conjugated goat anti-mouse IgG, 
diluted 600-fold in IF buffer, by incubation for $2 \mathrm{~h}$ at room temperature in darkness. After washing with IF buffer again, the slices were covered with DAKO Fluorescent Mounting Medium and observed by fluorescent microscopy (400 $\times$ magnification) with an IX-70 microscope (Olympus Europa GmbH, Hamburg, Germany). Control staining with preimmune sera gave no immunoreactive signals.

\section{Cell culture}

Cells were propagated in RPMI-1640 medium (rat insulinoma cells RINm5F) or DMEM (mouse insulinoma cells BTC6-F7) supplemented with $10 \%$ (v/v) heat-inactivated FCS, $100 \mathrm{U} / \mathrm{ml}$ penicillin, $100 \mu \mathrm{g} / \mathrm{ml}$ streptomycin. The cells were cultured at $37^{\circ} \mathrm{C}$ in a humidified atmosphere containing $95 \%(\mathrm{v} / \mathrm{v})$ air and $5 \%(\mathrm{v} / \mathrm{v}) \mathrm{CO}_{2}$.

\section{Isolation of pancreatic islets}

The isolated pancreas from 3-month-old male or female C57/BL6 mice were inflated with Gey-Gey buffer $(6 \cdot 5 \mathrm{~g} / 1$ $\mathrm{NaCl}, 2 \cdot 27 \mathrm{~g} / 1 \mathrm{NaHCO}_{3}, 0.37 \mathrm{~g} / 1 \mathrm{KCl}, 0 \cdot 212 \mathrm{~g} / 1 \mathrm{MgCl}_{2}$ $6 \mathrm{H}_{2} \mathrm{O}, \quad 0.74 \mathrm{~g} / 1 \quad \mathrm{MgSO}_{4} \cdot 7 \mathrm{H}_{2} \mathrm{O}, \quad 0 \cdot 421 \mathrm{~g} / 1 \quad \mathrm{Na}_{2} \mathrm{HPO}_{4}$, $0.04 \mathrm{~g} / 1 \mathrm{KH}_{2} \mathrm{PO}_{4}$, and $1.5 \mathrm{mg} / 1 \mathrm{CaCl}_{2}$ aerated with $\mathrm{CO}_{2} / \mathrm{O}_{2}$ for $20 \mathrm{~min}$ ) and were chopped into small pieces. After a short centrifugation ( $300 \boldsymbol{g}$ for $2 \mathrm{~s}$ ), the pellet was resuspended in Gey-Gey buffer containing $2 \mathrm{mg}$ collagenase XI (Sigma) per pancreas and was shaken in a water bath at $37^{\circ} \mathrm{C}$ followed by a subsequent centrifugation step $(300 \boldsymbol{g}$ for $5 \mathrm{~s})$. The pelleted islets were suspended in fresh buffer, picked, and cultured for $24 \mathrm{~h}$ in RPMI-1640 medium supplemented with $10 \%(\mathrm{v} / \mathrm{v})$ heat-inactivated FCS, $100 \mathrm{U} / \mathrm{ml}$ penicillin, $100 \mu \mathrm{g} / \mathrm{ml}$ streptomycin and with or without cytokines $(250 \mathrm{U} / \mathrm{ml} \mathrm{TNF}-\alpha, 2 \cdot 5 \mathrm{U} / \mathrm{ml}$ IL1 $\beta$, and $125 \mathrm{U} / \mathrm{ml}$ IFN- $\gamma$ ) at $37^{\circ} \mathrm{C}$ in a humidified atmosphere containing $95 \%(\mathrm{v} / \mathrm{v})$ air and $5 \%(\mathrm{v} / \mathrm{v}) \mathrm{CO}_{2}$.

\section{Semi-quantitative reverse transcription-PCR}

Total RNA was isolated using a commercial kit from Qiagen. cDNA was prepared by reverse transcription (RT) of $2 \mu \mathrm{g}$ total RNA using $0.5 \mu \mathrm{g}$ BamTT-primer ( $3^{\prime}$-CGC GGA TCC TTT TTT TTT TTT TTT TTT-5 ${ }^{\prime}$ ) and SuperScript II reverse transcriptase. Prx III was amplified with Taq DNA polymerase in a DNA thermal cycler (Eppendorf, Germany) using the following gene-specific primers: $\operatorname{Prx} I I I$ for: $5^{\prime}$-TAG CTA GCT AGA ATT CCT TGC GTG CTC TGA AGA TGG- $3^{\prime}$ and $P r x$ III rev: $5^{\prime}$-TAG CTA GCT AGG ATC CGC CTA CTG ATG GAC CTT CTC- $3^{\prime}$ with an expected product of $791 \mathrm{bp}$. The conditions for each cycle were $30 \mathrm{~s}$ at $94{ }^{\circ} \mathrm{C}, 40 \mathrm{~s}$ at $57^{\circ} \mathrm{C}$ and $60 \mathrm{~s}$ at $72^{\circ} \mathrm{C}(25$ cycles $)$.

\section{Tet-On-system}

PCR products containing amplified complete cDNA of Prx III were inserted into pUHD10-3 (Clontech) at the EcoRI and BamHI restriction sites. For the PCR, the primers $\operatorname{Prx} I I I$ for EcoRI (5'-TAG CTA GCT AGA ATT CCT TGC GTG CTC TGA AGA TGG-3') and $\operatorname{Prx}$ III rev BamHI $\left(5^{\prime}-\mathrm{TAG}\right.$ CTA GCT AGG ATC CGC CTA CTG ATG GAC CTT CTC- $3^{\prime}$ ) were used for sense orientation, while Prx III for BamHI (5'-TAG CTA GCT AGG ATC CCT TGC GTG CTC TGA AGA TGG-3') and Prx III rev EcoRI (5'-TAG CTA GCT AGA ATT CGC CTA CTG ATG GAC CTT CTC- $3^{\prime}$ ) were used for antisense orientation.

From both the constructs, a $1573 \mathrm{bp}$ fragment, containing the complete transcriptional unit, was cut out by digestion with XhoI and KasI. After a fill in of the $5^{\prime}$-overhangs, it was inserted into the vector pUHD172-1neo with blunt end (Clontech) at PvuII restriction site. The neo cassette of pUHD172-1neo was removed before and inserted again after this cloning step using Xhol. For stable transfection of RINm5F cells with Lipofectamine 2000 (Invitrogen), the construct was linearized with BspHI. The transfected cells were selected using $500 \mu \mathrm{g} / \mathrm{ml} \mathrm{G} 418$. The expression of Prx III mRNA in sense or antisense orientation was induced by $1 \mu \mathrm{g} / \mathrm{ml}$ doxycyclin for 4 days. In preliminary studies, the expression of the Tet repressor or the time-dependent induction of the Prx III construct was detected by northern blots (data not shown).

\section{Western blot}

RINm5F cells were scraped with $100 \mu \mathrm{l}$ lysis buffer $(25 \mathrm{mmol} / 1 \mathrm{Tris}-\mathrm{HCl} \mathrm{pH} 7 \cdot 4,50 \mathrm{mmol} / \mathrm{l} \mathrm{NaF}, 0 \cdot 1 \mathrm{~mol} / 1$ $\mathrm{NaCl}, 5 \mathrm{mmol} / \mathrm{l}$ EGTA, $1 \mathrm{mmol} / \mathrm{l}$ EDTA, $10 \mathrm{mmol} / \mathrm{l}$ $\mathrm{Na}_{4} \mathrm{P}_{2} \mathrm{O}_{7}, 1 \%(\mathrm{v} / \mathrm{v})$ Triton $\mathrm{X}-100,9 \cdot 2 \%(\mathrm{w} / \mathrm{v})$ sucrose, and protease inhibitors), shock frozen in liquid nitrogen, and centrifuged ( $5 \mathrm{~min}, 13400 \mathrm{~g}, 4^{\circ} \mathrm{C}$ ).

Isolated islets were lysed by the addition of $50 \mu \mathrm{l}$ RIPA buffer $(50 \mathrm{mmol} / 1$ Tris-HCl, $\mathrm{pH} 7 \cdot 4 ; 1 \%$ (v/v) NP-40; $0 \cdot 25 \%(\mathrm{w} / \mathrm{v}) \mathrm{Na}$ deoxycholate; $150 \mathrm{mmol} / \mathrm{l} \mathrm{NaCl} ; 1 \mathrm{mmol} / 1$ EDTA; and protease inhibitors) to 100 islets and were frozen in liquid nitrogen, followed by a centrifugation step after thawing.

Proteins $(10$ or $20 \mu \mathrm{g})$ were separated by $12 \cdot 5 \%(\mathrm{w} / \mathrm{v})$ SDS-PAGE and electroblotted onto nitrocellulose membranes using a semidry blotter. The blot was blocked with Roti-Block (Roth, Karlsruhe, Germany) for $1 \mathrm{~h}$ at room temperature and subsequently incubated in a 1:2000 dilution of a polyclonal rabbit anti-PRX III or anti-GAPDH antiserum in IF buffer with $5 \%(\mathrm{w} / \mathrm{v}) \mathrm{BSA}, 0 \cdot 05 \%(\mathrm{w} / \mathrm{v})$ saponin, $0 \cdot 1 \%(\mathrm{w} / \mathrm{v})$ sodium azide in PBS, $\mathrm{pH} 7 \cdot 4$ in a 1 : 10000 dilution of monoclonal rabbit anti-iNOS antibody (Sigma-Aldrich) or 1:1000 dilution of monoclonal rabbit antibody directed against cleaved PARP-1 (Cell Signaling Technology). After washing the blot with PBS/Tween 0.05\% (v/v), a HRP-conjugated goat anti-rabbit IgG (1:10 000) was used as secondary antibody. Detection of bound antibody was performed with LumiGLO reagent and peroxide (Cell Signaling Technology). 


\section{Intracellular oxidant production}

Cells $\left(7 \times 10^{4}\right)$ grown in $35 \mathrm{~mm}$ dishes were treated for 4 days with/without $1 \mu \mathrm{g} / \mathrm{ml}$ doxycyclin and for $1 \mathrm{~h}$ with $1 \mathrm{mmol} / 1$ $\mathrm{H}_{2} \mathrm{O}_{2}$. The cells were trypsinized and incubated for $2 \mathrm{~h}$ with $20 \mu \mathrm{M}$ DCFH-DA (Molecular Probes/Invitrogen Darmstadt, Germany) in $300 \mu \mathrm{l} \mathrm{PBS}$ at $37^{\circ} \mathrm{C} .2^{\prime}, 7^{\prime}$-dichlorfluoresceindiacetate (DCFH-DA) is permeable, and it is cleaved by endogenous esterases to DCFH. The intracellular oxidation of DCFH by ROS generates the green fluorescent DCF, which is not further permeable and can be analyzed by a FACScan, measuring the emission at $530 \mathrm{~nm}$. The fluorescence intensity is proportional to the amount of intracellular ROS.

\section{Mitochondrial transmembrane potential $\left(\Delta \psi_{m}\right)$}

Cells $\left(7 \times 10^{4}\right)$, grown in $35 \mathrm{~mm}$ dishes, were treated for 4 days with/without $1 \mu \mathrm{g} / \mathrm{ml}$ doxycyclin and for $48 \mathrm{~h}$ with a mix of $100 \mathrm{U} / \mathrm{ml} \mathrm{TNF}-\alpha, 50 \mathrm{U} / \mathrm{ml} \mathrm{IL} 1 \beta$, and $100 \mathrm{U} / \mathrm{ml}$ IFN- $\gamma$. The trypsinized cells were centrifuged $(400 \mathrm{~g})$ together with the supernatant to harvest all the cells, adherent and detached. Next, the supernatant was aspirated, and the cells were resuspended in $1 \mathrm{ml}$ medium with $50 \mathrm{nM}$ $3,3^{\prime}$-dihexyloxacarbocyanine iodide $\left(\mathrm{DiOC}_{6}(3)\right.$; Mobitec SA, Eupen, Belgium) and incubated for $30 \mathrm{~min}$ at $37^{\circ} \mathrm{C}$. After incubation time, the cells were centrifuged $(1 \mathrm{~min}$, $500 \mathrm{~g}$ ), resuspended in $300 \mu \mathrm{l} \mathrm{PBS}$, and analyzed (at least 10000 cells) using a FACSCalibur and CellQuest software. Data ware gated to exclude debris.

\section{Activation of caspase-3 and -9}

Cells $\left(7 \times 10^{4}\right)$ grown in $35 \mathrm{~mm}$ dishes were treated for 4 days with/without $1 \mu \mathrm{g} / \mathrm{ml}$ doxycyclin and for $9 \mathrm{~h}$ with $100 \mathrm{U} / \mathrm{ml}$ TNF- $\alpha, 50 \mathrm{U} / \mathrm{ml}$ IL1 $\beta, 100 \mathrm{U} / \mathrm{ml}$ IFN- $\gamma, 4$ mmol/1 STZ, or $4 \mathrm{mmol} / 1$ alloxan. The trypsinized cells were centrifuged $(400 \mathrm{~g})$ together with the supernatant to harvest all the cells, adherent and detached. The sediment was resuspended in $100 \mu \mathrm{l}$ lysis buffer $\left(10 \mathrm{mmol} / \mathrm{l}\right.$ Tris- $\mathrm{HCl}, 10 \mathrm{mmol} / 1 \mathrm{NaH}_{2} \mathrm{PO}_{4}$, $10 \mathrm{mmol} / 1 \mathrm{Na}_{4} \mathrm{P}_{2} \mathrm{O}_{7}, 130 \mathrm{mmol} / 1 \mathrm{NaCl}$, and 1\% (v/v) Triton $\mathrm{X}-100)$ before the addition of $130 \mu \mathrm{l}$ caspase buffer $(20 \mathrm{mmol} / \mathrm{l}$ HEPES pH 7·5, $0 \cdot 1 \mathrm{M} \mathrm{NaCl}, 2 \mathrm{mmol} / 1$ dithiothreitol, $10 \%$ (v/v) glycerol, $25 \mu \mathrm{g} / \mathrm{ml}$ caspase substrate). We used Ac-DEVD-AFC (Bachem, Heidelberg, Germany) as substrate for caspase-3 and Ac-LEHD-AFC (Bachem) for caspase-9. After an incubation step for $2 \mathrm{~h}$ at $37^{\circ} \mathrm{C}$, the release of fluorescent AFC (390 nm excitation and $510 \mathrm{~nm}$ emission) by activated caspases was determined using a Wallac Victor fluorescence photometer (Perkin Elmer, Waltham, MA, USA).

\section{$R I A$}

Insulin secretion was analyzed from $3 \times 10^{6}$ wild-type or stably transfected RINm5F cells treated for 4 days with/without $1 \mu \mathrm{g} / \mathrm{ml}$ doxycyclin in $2 \mathrm{ml}$ RPMI-1640 medium supplemented with $10 \%(\mathrm{v} / \mathrm{v})$ heat-inactivated FCS, $100 \mathrm{U} / \mathrm{ml}$ penicillin, $100 \mu \mathrm{g} / \mathrm{ml}$ streptomycin using a rat insulin RIA kit (Linco Research, St Charles, MO, USA) according to the manufacturer's protocol. The samples were counted by a multi-crystal gamma counter LB2104 (Berthold) for 1 min.

\section{ELISA}

Glucose-stimulated insulin secretion was analyzed by using the Mercodia Ultrasensitive Insulin ELISA kit (Mercodia, AB, Uppsala, Sweden). Briefly, wild-type or stably transfected RINm5F cells were seeded into 24 -well plates $\left(3 \times 10^{5}\right.$ cells/well per $2 \mathrm{ml}$ ) and cultured for 4 days with $1 \mu \mathrm{g} / \mathrm{ml}$ doxycyclin in $2 \mathrm{ml}$ RPMI-1640 medium containing $3.3 \mathrm{mmol} / 1$ glucose and supplemented with $10 \%$ (v/v) FCS. The cells were cultured in the presence or absence of $80 \mu \mathrm{mol} / 1 \mathrm{H}_{2} \mathrm{O}_{2}$ for a further $24 \mathrm{~h}$. Thereafter, the medium was replaced by $1 \mathrm{ml}$ RPMI containing either $3 \cdot 3$ or $20 \mathrm{mmol} / \mathrm{l}$ glucose, and after $2 \mathrm{~h}$, the cell-free supernatants were collected for determination of insulin secreted into the medium.

\section{Cell viability}

Cell viability was determined by applying the LIVE/DEAD Viability/Cytotoxicity Kit (Molecular Probes) following the instructions of the manufacturer. Briefly, wild-type or stably transfected RINm5F cells were seeded into 96-well plates $\left(1 \times 10^{4}\right.$ cells/well per $0.2 \mathrm{ml}$; four replicates each) and cultured for 4 days with/without $1 \mu \mathrm{g} / \mathrm{ml}$ doxycyclin in $2 \mathrm{ml}$ RPMI-1640 medium supplemented with 10\% (v/v) FCS. The cells were cultured for an additional $60 \mathrm{~min}$ in the presence or absence of $1 \mathrm{mmol} / 1 \mathrm{H}_{2} \mathrm{O}_{2}$. Then, the medium was replaced by $200 \mu \mathrm{l}$ PBS containing $20 \mu \mathrm{mol} / 1$ ethidium homodimer- 1 and $80 \mu \mathrm{mol} / 1$ calcein AM, and the cells were incubated for $20 \mathrm{~min}$ at $37^{\circ} \mathrm{C}$. Cells were examined by fluorescence microscopy using an Axiovert 135 TV (Carl Zeiss, Jena, Germany) and the optical filter set No. 23 (Carl Zeiss). The number of green (viable) and red (dead) cells was counted from three randomly chosen areas in each case.

\section{Statistical analyses}

Statistical analyses were performed using GraphPad Prism version 3 software. Means \pm s.E.M. were calculated from at least three different experiments. Data were analyzed using a nonparametric Mann-Whitney test. Differences were considered statistically significant at $P<0 \cdot 05$.

\section{Results}

Prx III is expressed in insulin-producing cells

First, we demonstrated the presence of PRX III in insulin-secreting cells using immunofluorescence and RT-PCR (Fig. 1). 

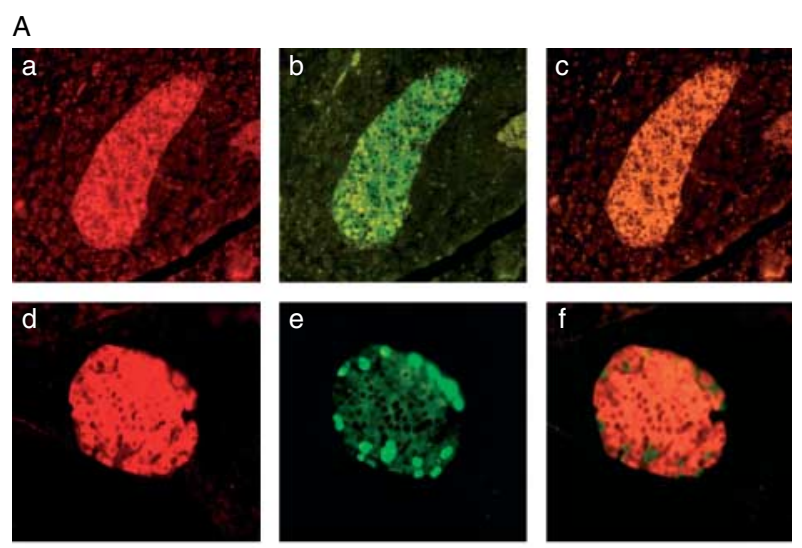

B

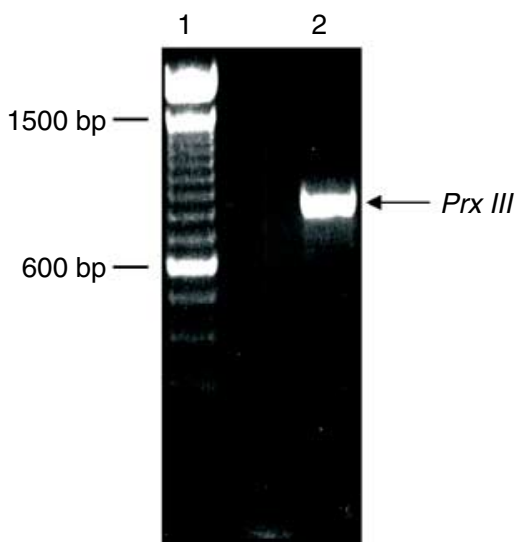

Figure 1 (A) Immunohistochemistry. Paraffin slices of Balb/c mouse pancreas were stained with antisera against PRX III (a, c, d, and $f$, red), insulin (b and c, green), or glucagon (e and $f$, green). In the overlay ( $c$ and $f$ ), colocalization of red and green signals resulted in an orange color. Control staining with preimmune sera gave no immunoreactive signals. (B) Semi-quantitative RT-PCR. CDNA was prepared by reverse transcription of $2 \mu \mathrm{g}$ total RNA from mouse insulinoma cells $\beta$ TC6-F7. Prx III was amplified with an expected product of $791 \mathrm{bp}$ (lane 2). Molecular weight marker (lane 1).

Using paraffin slices of pancreas from $\mathrm{Balb} / \mathrm{c}$ mice (Fig. 1A), we demonstrated that the green fluorescence associated with either insulin (b and $c$ ) or glucagon (e and $f$ ) was localized to the central islet core $(b$ and $c$ ) or to the surrounding $\alpha$ cells (e and f). The red fluorescent signals represented PRX III (a and d). Immunotargeted signals were not visible when the corresponding preimmune sera were used (data not shown). The colocalization of PRX III with insulin resulted in yellow immunostaining in the overlay (c). There was no colocalization of PRX III and glucagon detectable in the overlay (f). PRX III was predominantly expressed in $\beta$ cells, only slight background signals were observed in exocrine cells of the pancreas.

To confirm the expression of Prx III in insulin-producing cells, mouse insulinoma cells $\beta$ TC6-F7 were cultured for $24 \mathrm{~h}$. The mRNA was examined by semi-quantitative RT-PCR (Fig. 1B). We detected $\operatorname{Pr} x$ III mRNA in the insulinoma cells with an expected RT-PCR product of $791 \mathrm{bp}$.
Cytokine stress increased the expression of Prx III in isolated islets

To study whether the PRX III system is induced after stress, islets of Langerhans from C57/BL6 mice were exposed to a mixture of cytokines $(100 \mathrm{U} / \mathrm{ml}$ TNF- $\alpha, 50 \mathrm{U} / \mathrm{ml}$ IL $1 \beta$, and $100 \mathrm{U} / \mathrm{ml}$ IFN- $\gamma$ ). The subsequent western blots revealed an increased amount of PRX III in cytokine-stressed cells compared with the control cells incubated without cytokines (Fig. 2).

Exogenously triggered expression of Prx III in stably transfected cells

To determine the importance of PRX III in $\beta$ cells, we established stably transfected insulinoma cells, in which Prx III is inducibly upregulated or downregulated in dependence of doxycyclin. For this purpose, we applied the inducible Tet-On-system. We transfected RINm5F cells with a construct composed of two transcriptional units. In the first unit, a regulator protein called reverse tetracycline-controlled transactivator (rtTA) is expressed constitutively. In the second unit, a tetracycline response element (TRE) fused to a minimal promoter drives the gene of interest. Only in the presence of doxycyclin, the over-expressed rtTA binds to the TRE and activates the transcription of the target gene. In our cell system, we over-expressed Prx III using the cDNA in sense orientation or suppressed it via the expression of an antisense RNA. Next, we verified the functionality of the stably transfected cells (Fig. 3). We regulated the expression of the Prx III construct by incubation in the presence or absence of doxycyclin for 4 days. Northern blot analyses with a digoxigenin-labeled DNA probe revealed a regulation of
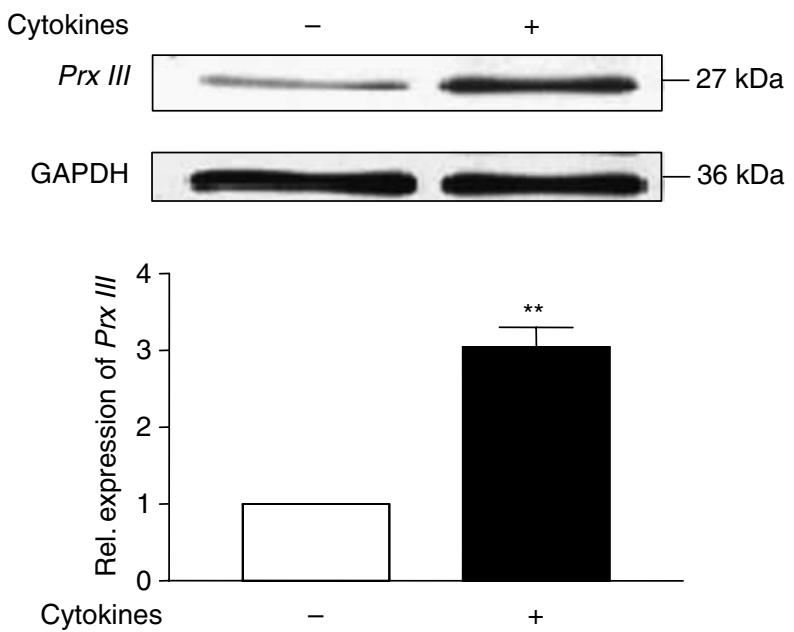

Figure 2 Western blot. Isolated islets from C57/BL6 mice were treated for $24 \mathrm{~h}$ with cytokines $(250 \mathrm{U} / \mathrm{ml} \mathrm{TNF}-\alpha, 2 \cdot 5 \mathrm{U} / \mathrm{ml} \mathrm{IL1} \beta$, and $125 \mathrm{U} / \mathrm{ml} \mathrm{IFN}-\gamma)$. Proteins $(20 \mu \mathrm{g})$ were subjected to western blot analysis with anti-PRX III. Anti-GAPDH was utilized as a loading control. The results of four independent experiments were statistically analyzed $(* * P<0 \cdot 005)$. 
A
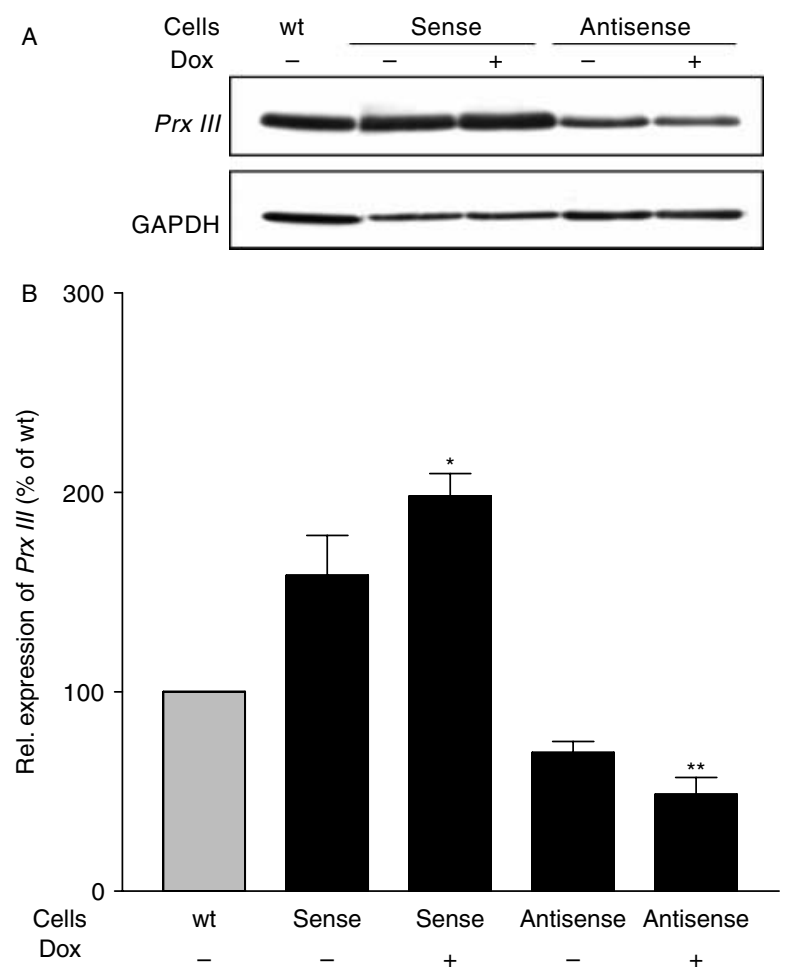

Figure 3 Tet-On-system. (A) Western blot. Proteins $(20 \mu \mathrm{g})$, prepared from wild-type (wt) or stably transfected RINm5F cells over- (sense) or under- (antisense) expressing Prx III, which had been treated with/without $1 \mu \mathrm{g} / \mathrm{ml}$ doxycyclin (dox) for 4 days, were estimated by western blotting with an antibody directed against PRX III. GAPDH was employed as loading control. (B) Statistical analysis. Gray scale values of all experiments $(n \geq 3)$ were statistically analyzed, and significant differences between ' + ' and ' - ' dox were indicated $\left({ }^{*} P<0.05\right.$ and $\left.{ }^{* *} P<0.005\right)$.

transfected $\operatorname{Pr} x$ III in the induced cells compared to untreated cells and untransfected cells (data not shown). Furthermore, the expression level of $\operatorname{Prx} I I I$ was analyzed by western blotting (Fig. 3). The amount of PRX III protein was altered by the expression of the sense or the antisense construct in the stably transfected cells after treatment with doxycyclin for 4 days compared to the untreated and untransfected cells. Over-expression of the sense construct resulted in a significant increase in protein amounts of PRX III (nearly twofold), while the antisense construct highly significantly diminished the $\operatorname{Pr} x$ III expression to about 50\%. We additionally observed that the Tet-On-system was leaky. Nevertheless, there was a clear difference between induced and noninduced cells: doxycyclin adjusted the PRX III amount from 120 to $177 \%$ in the sense clone and from $69 \cdot 5$ to $48 \cdot 5 \%$ in the antisense clone. So a difference of 177 vs $48 \cdot 5 \%$ between the sense and antisense clones as physiological consequences of upregulation and downregulation of $\operatorname{Prx}$ III is observed. The cells were incubated with doxycyclin for 4 days (a period which had been found to be optimal) and subsequently treated with diverse stressors.
PRX III lowers intracellular oxidant production after stress with $\mathrm{H}_{2} \mathrm{O}_{2}$ and protects from cell death

Different pro-apoptotic stimuli enhance the production of oxygen free radicals in cells. The intracellular redox status was assessed by the level of intracellular ROS, using the oxidationsensitive fluorescent marker DCFH-DA (Fig. 4).

After incubation for $1 \mathrm{~h}$ with $1 \mathrm{mmol} / \mathrm{H}_{2} \mathrm{O}_{2}$ (a concentration that causes a strong stress situation), the intensity of fluorescence of intracellular oxidized DCF was analyzed by a flow cytometer at $530 \mathrm{~nm}$. After treating cells with $\mathrm{H}_{2} \mathrm{O}_{2}$, an increased intracellular oxidation of DCFH could be observed, which was partially but not significantly reduced in $\operatorname{Prx} I I I$ over-expressing cells (Fig. 4A). In cells transfected with $\operatorname{Pr} x$ III antisense construct, the amount of oxidized DCFH was approximately doubled in the presence of $\mathrm{H}_{2} \mathrm{O}_{2}$, while PRX III depletion by doxycyclin led to a dramatic, nearly fourfold, increase in oxidized DCFH (Fig. 4B).

Cell viability was analyzed using the LIVE/DEAD Viability/Cytotoxicity kit (Molecular Probes). The prolonged exposure to doxycyclin $(96 \mathrm{~h})$ did not compromise cell viability to a significant extent, as $<0 \cdot 4 \%$ of cells appeared nonviable (stained red by ethidium bromide homodimer) irrespective of the presence $(+$ dox) or absence (-dox) of doxycyclin. When Prx III antisense transfectants were subjected to strong oxidative stress by exposure to $1 \mathrm{mmol} / 1 \mathrm{H}_{2} \mathrm{O}_{2}$ for $60 \mathrm{~min}$, cell death was increased to $18 \cdot 7 \pm 1 \cdot 1 \%(-$ dox $)$ or $17 \cdot 6 \pm 1 \cdot 9 \%$ ( + dox $)$ (Fig. 4C and D). Over-expression of $\operatorname{Prx} I I I$ leads to a clear reduction in the amount of nonviable cells (+ dox: $6 \cdot 18 \pm 0 \cdot 9 \%, P<0 \cdot 01$; -dox: $13 \cdot 99 \pm 2 \cdot 3 \%, P=$ NS; Fig. $4 \mathrm{C}$ and D).

\section{PRX III prevented the induction of $i$ NOS after stress with cytokines}

The iNOS can produce large amounts of $\mathrm{NO}^{\circ}$, which leads to cytochrome $c$ release from mitochondria, DNA fragmentation, and apoptosis. Stably transfected RINm5F cells were induced for 4 days with doxycyclin and treated for $24 \mathrm{~h}$ with cytokines. The western blot analysis with anti-iNOS demonstrated that $\operatorname{Prx}$ III over-expression reduced the induction of iNOS after stress with IL1 $\beta$ or the proinflammatory cytokine mix (Fig. 5A). However, downregulation of $\operatorname{Pr} x$ III resulted in an additional increase in iNOS expression due to these stressors (Fig. 5B).

\section{PRX III maintained the mitochondrial membrane potential during stress}

We next investigated whether PRX III was able to prevent apoptosis. There are two different apoptotic pathways, intrinsic and extrinsic. During the intrinsic pathway of apoptosis, peroxidation of cardiolipin in the mitochondrial inner membrane results in an impaired mitochondrial membrane potential and in the release of cytochrome $c$, which triggers the activation of caspase-9. To analyze such 

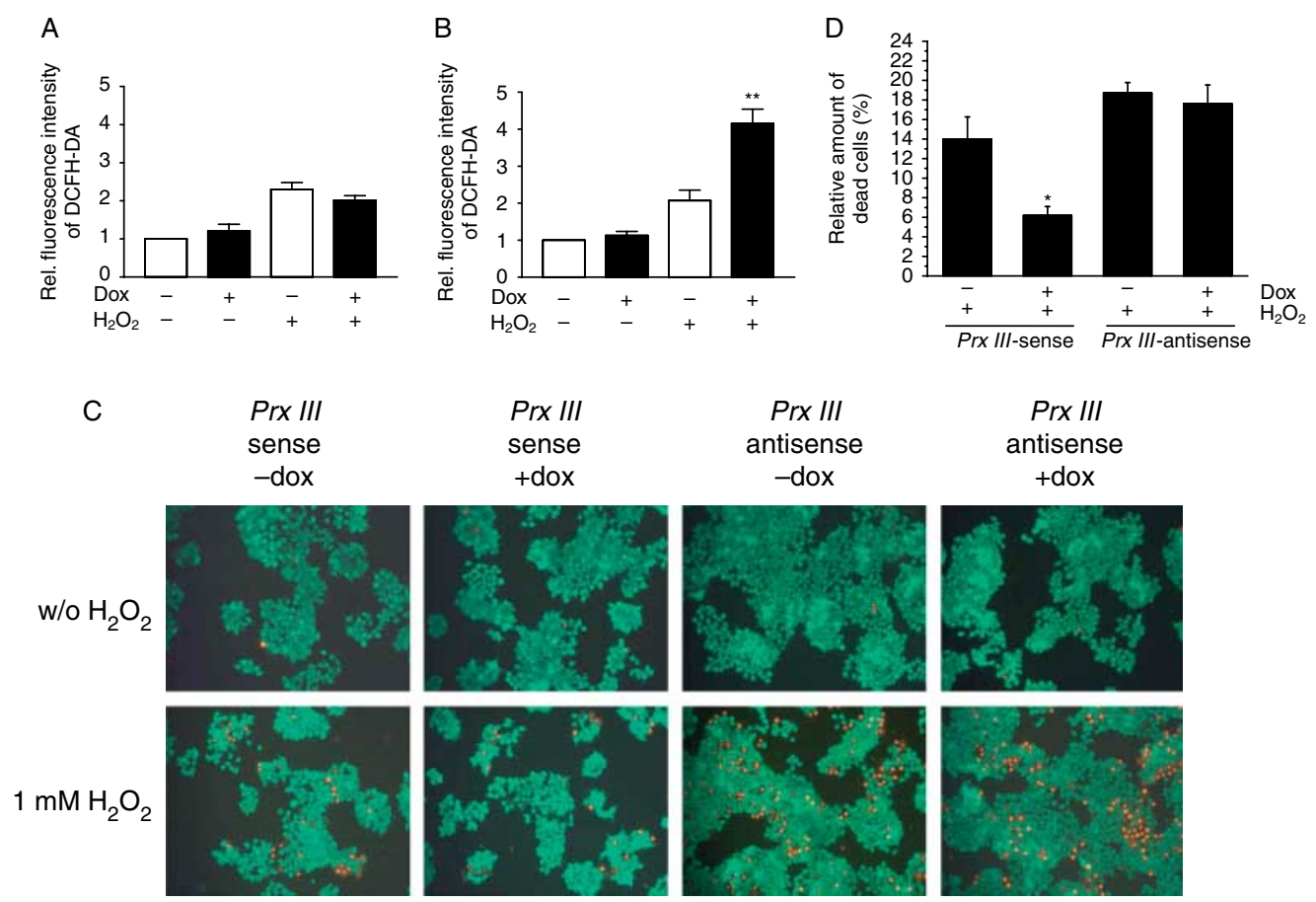

Figure 4 Effects of the expression of Prx III on intracellular oxidant concentration and cell viability. Stably transfected RINm5F cells, expressing the (A) sense or (B) antisense construct, were treated for 4 days with/without $1 \mu \mathrm{g} / \mathrm{ml}$ doxycyclin (dox) and for $1 \mathrm{~h}$ with $1 \mathrm{mmol} / \mathrm{I}_{2} \mathrm{O}_{2}$. The trypsinized cells were incubated for $2 \mathrm{~h}$ with $20 \mu \mathrm{M}$ DCFH-DA in $300 \mu \mathrm{PBS}$ at $37^{\circ} \mathrm{C}$. The intracellular oxidant production was analyzed by a FACScan. (C and D) LIVE/DEAD assay demonstrating that Prx III expression protects from cell death due to a 60 -min exposure to $1 \mathrm{mmol} / \mathrm{I} \mathrm{H}_{2} \mathrm{O}_{2}$. Viability of cells not exposed to $\mathrm{H}_{2} \mathrm{O}_{2}$ was $>96 \cdot 6 \%$ irrespective of the cells being wild-type or transfected with $\mathrm{Prx}$ III sense or antisense constructs, or the presence or absence of doxycyclin respectively $\left({ }^{*} P<0 \cdot 01\right)$.

processes, we used $\operatorname{DiOC}_{6}(3)$, a fluorescent marker of $\Delta \psi_{\mathrm{m}}$. The stably transfected RINm5F cells were induced for 4 days with doxycyclin and stressed for $48 \mathrm{~h}$ with pro-inflammatory cytokines. After staining with $\operatorname{DiOC}_{6}(3)$, the cells were analyzed for $\Delta \psi_{\mathrm{m}}$ on a FACSCalibur. Unstressed cells were visible as a peak in the right side of the diagram (M1; Fig. 6), while stressed cells with an impaired mitochondrial membrane potential were detectable on the left side. Over-expression of Prx III resulted in a decrease in apoptotic cells after stress and in an increased peak within the M1 region (Fig. 6).

\section{PRX III prevented the activation of caspase- 3 and -9 after stress}

While only the intrinsic apoptotic pathway involves mitochondria and activates caspase-9, caspase- 3 is activated via both ways. To analyze whether PRX III is able to protect against mitochondrial damages induced by diabetogenic substances and pro-inflammatory cytokines, stably transfected cells were incubated in the presence (black bars) or absence (white bars) of doxycyclin for 4 days followed by a treatment with IL1 $\beta$ (Fig. 7A-D) for $9 \mathrm{~h}$. The caspase- 3 and -9 activities were decreased by enhanced amounts of PRX III (A and C). Downregulation of this mitochondrial enzyme resulted in increased caspase-3 and -9 activities (B and D). Similar experiments with cells treated with STZ (E-H) or TNF- $\alpha$ or IFN- $\gamma$ (data not shown) resulted in comparable results. Thus, we have demonstrated that enhanced expression of $\operatorname{Prx} I I I$ reduced apoptosis, while downregulation of this mitochondrial enzyme resulted in increased caspase-3 and -9 activities and thus apoptosis.

\section{PRX III prevented the cleavage of PARP-1}

PARP is an abundant nuclear enzyme that mediates the repair of DNA single strand breaks via the activation and recruitment of DNA repair enzymes. In apoptotic cells, PARP is cleaved by activated caspase- 3 . We analyzed cleaved PARP as an apoptosis marker using stably transfected RINm5F cells, which were induced for 4 days with doxycyclin and treated for $24 \mathrm{~h}$ with pro-inflammatory cytokines or STZ. We utilized western blot analyses with an anti-cleaved PARP-1 antibody. In RINm5F cells over-expressing Prx III, the cleavage of PARP-1 was significantly reduced after cytokine- or STZ-induced stress (Fig. 8A), while downregulation of Prx III resulted in increased PARP cleavage in the cytokine- or STZ-treated cells (Fig. 8B). 

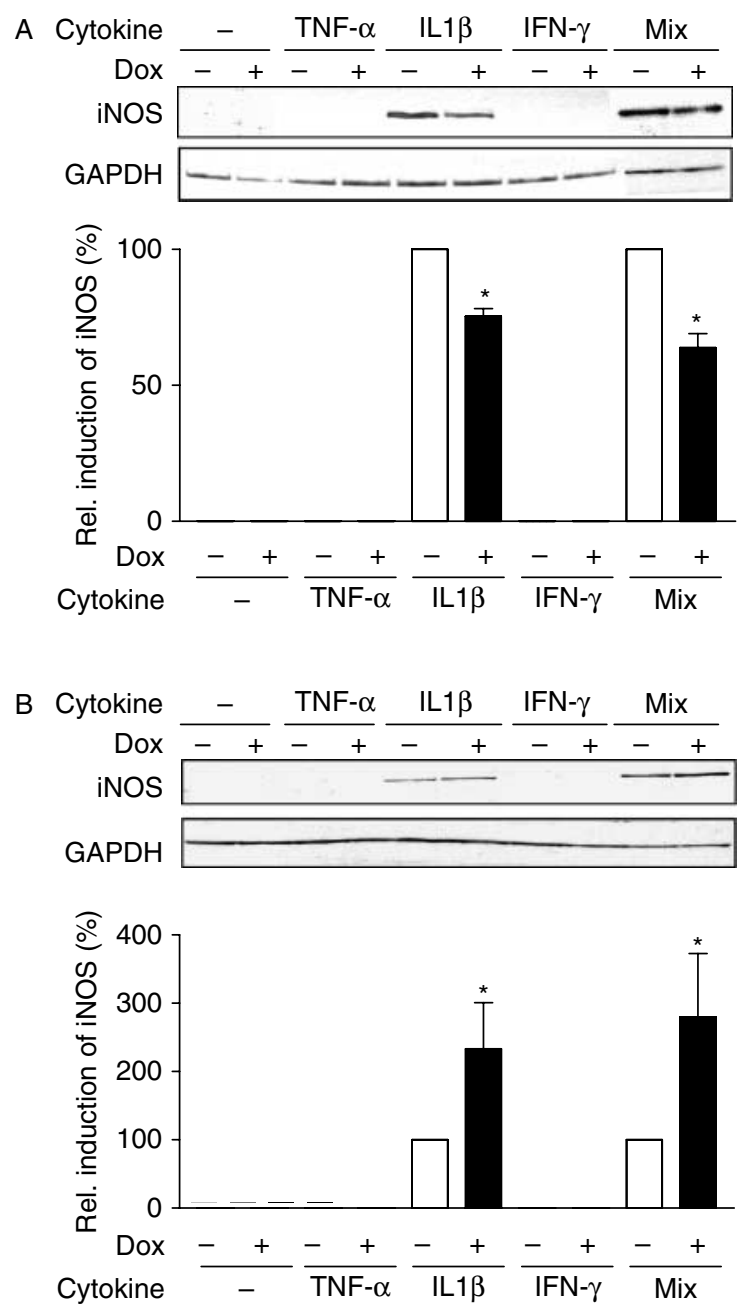

Figure 5 Western blot. Stably transfected RINm5F cells with the Prx III construct in (A) sense or (B) antisense orientation were induced for 4 days with/without $1 \mu \mathrm{g} / \mathrm{ml}$ doxycyclin (dox) and treated for $24 \mathrm{~h}$ with cytokines $(100 \mathrm{U} / \mathrm{ml} \mathrm{TNF}-\alpha, 50 \mathrm{U} / \mathrm{ml} \mathrm{IL} 1 \beta$, and $100 \mathrm{U} / \mathrm{ml} \mathrm{IFN}-\gamma)$. Protein $(20 \mu \mathrm{g})$ was extracted and examined by western blots with an antibody directed against iNOS. GAPDH was utilized as a loading control. The intensity of the signals generated in three independent experiments and compared to GAPDH was statistically analyzed $(* P<0 \cdot 05)$.

\section{PRX III maintains the insulin secretion during stress}

Finally, RIA of released insulin over $24 \mathrm{~h}$, when cells were incubated in RPMI media, confirmed that PRX III deficiency resulted in impaired basal insulin secretion. Over-expression of Prx III slightly increased the basal secretion of insulin, while the downregulation of $\operatorname{Prx} I I I$ resulted in significantly reduced basal insulin secretion and thus concentration in the culture medium (Fig. 9A).

Analyses of the glucose-stimulated insulin release revealed that - as expected - wild-type RINm5F cells show a weak glucose-dependent increase in insulin secretion only.
However, exposure of cells to $\mathrm{H}_{2} \mathrm{O}_{2}$ significantly reduced insulin release from wild-type cells. This effect of $\mathrm{H}_{2} \mathrm{O}_{2}$ was also apparent in $\operatorname{Prx} I I I$ antisense cells, but was completely abrogated in cells over-expressing $\operatorname{Prx} I I I$ (sense). Under high glucose conditions $(20 \mathrm{mmol} / \mathrm{l})$, insulin secretion was enhanced in $\operatorname{Prx} I I I$ antisense cells. However, this effect was not observed in Prx III sense cells (Fig. 9B).

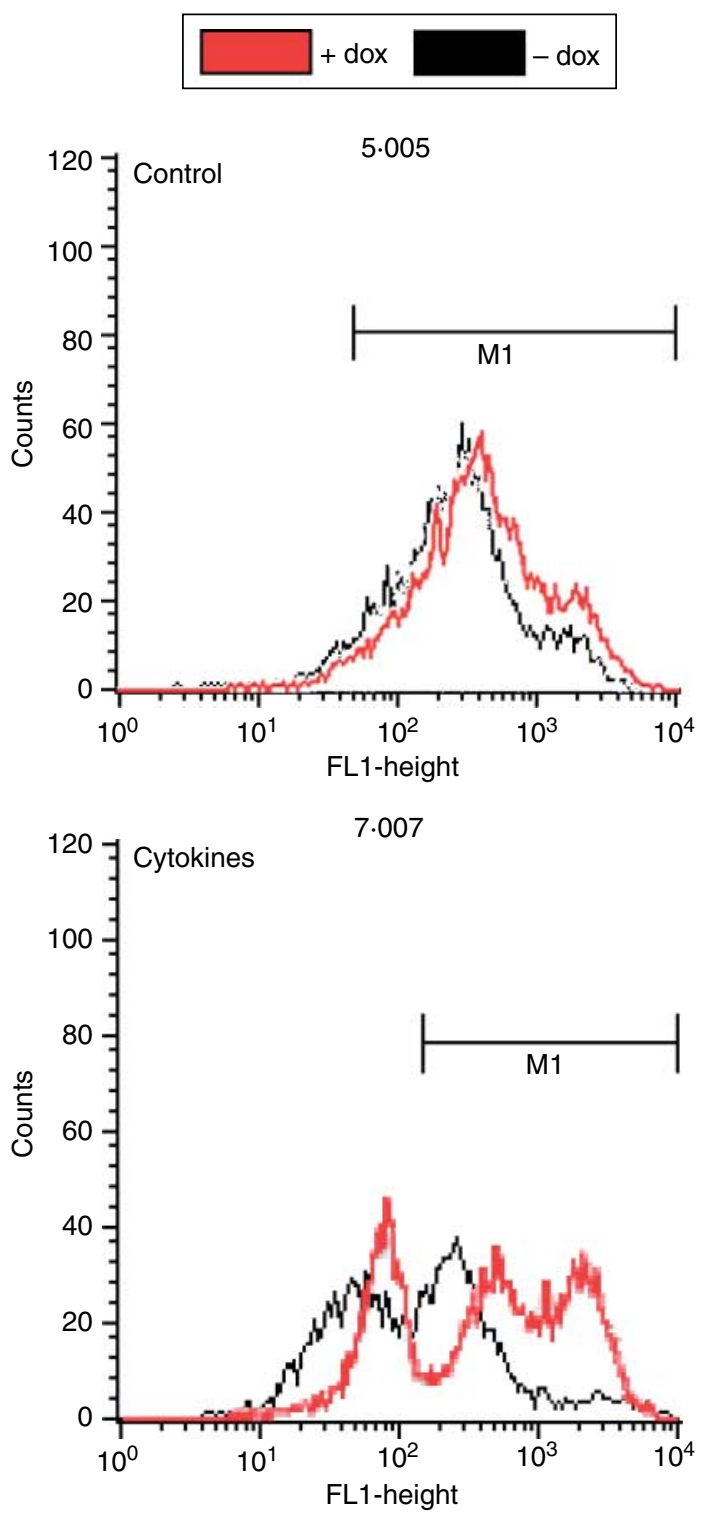

Figure 6 Analysis of mitochondrial membrane potential $\left(\Delta \psi_{\mathrm{m}}\right)$. Stably transfected RINm5F cells over-expressing Prx III were induced for 4 days with/without $1 \mu \mathrm{g} / \mathrm{ml}$ doxycyclin (dox) and stressed for $48 \mathrm{~h}$ with cytokines $(100 \mathrm{U} / \mathrm{ml} \mathrm{TNF}-\alpha, 50 \mathrm{U} / \mathrm{ml} \mathrm{IL1} \beta$,

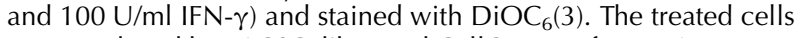
were analyzed by FACSCalibur and CellQuest software. Nonstressed cells induced for 4 days with/without $1 \mu \mathrm{g} / \mathrm{ml}$ doxycyclin were used as a control. 

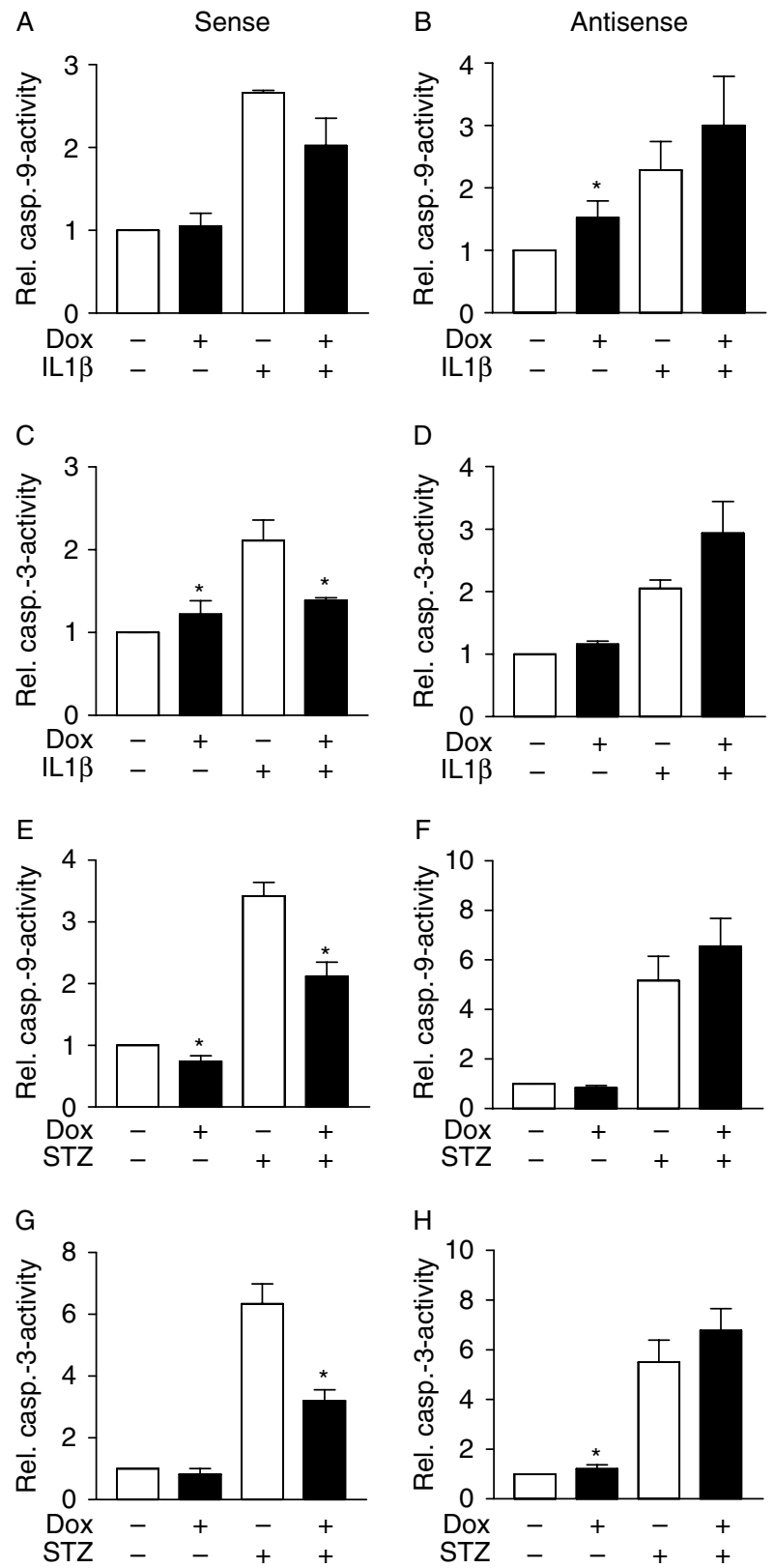

Figure 7 Determination of caspase- 9 and -3 activities. Cell lysates from stably transfected RINm5F cells, over- (A, C, E, and G) or under-expressing (B, D, F, and $\mathrm{H}) \operatorname{Prx} I I I$, were treated for 4 days with/without $1 \mu \mathrm{g} / \mathrm{ml}$ doxycyclin (dox) and for $24 \mathrm{~h}$ with $50 \mathrm{U} / \mathrm{ml}$ IL1 $\beta$ (A-D) or $4 \mathrm{mmol} / \mathrm{I}$ streptozotocin (STZ) $(\mathrm{E}-\mathrm{H})$ to determine caspase-9 (A, B, E, and F) and -3 (C, D, G, and H) activities, which was assayed by measuring the enzymatic hydrolysis of the added substrates LEHD-AFC or DEVD-AFC respectively. The released amount of AFC was determined with the fluorescence microplate reader Wallac 1420 Victor at $390 \mathrm{~nm}$ (excitation) and $510 \mathrm{~nm}$ (emission). Values were related to the protein content and were statistically analyzed $(* P<0 \cdot 05)$.

\section{Discussion}

Considering that during pathogenesis of type 1 (insulindependent) diabetes, the insulin-producing $\beta$ cells are destroyed by immune-mediated oxidative and nitrosative stress (Mandrup-Poulsen et al. 1990), and taking into account that $\beta$ cells are more sensitive to oxidative stress than many other cells (Lenzen et al. 1996, Tiedge et al. 1997), we analyzed whether PRXs are present in these cells and whether they are sufficient to prevent dysfunction and cell damage. Previously we reported that the expression of $\operatorname{Prx} I$ and $I I$ was detectable in $\alpha$ as well as in $\beta$ cells (Bast et al. 2002). It is well known that $\beta$ cells express low levels of most antioxidant enzymes such as $\mathrm{Cu} / \mathrm{ZnSOD}, \mathrm{MnSOD}$, catalase, and Gpx (Grankvist et al. 1981, Lenzen et al. 1996, Tiedge et al. 1997) than liver and kidney cells. Moreover, in diabetes-prone BB rats and diabetic patients, a further reduction in the islet antioxidative status was observed, thus making $\beta$ cells particularly susceptible to damage by radicals following exposure to cytokines or activated immune cells (L'Abbe \& Trick 1994, Maxwell et al. 1997). Indeed, we have found that $\operatorname{Pr} I$ expression was dramatically reduced in the islets of diabetogenic NOD mice (data not shown). Here we investigated whether the mitochondrial thioredoxin-2-PRX III system could be helpful in preventing oxidative stressinduced damage or destruction of insulin-producing cells. The analysis of $\operatorname{Prx} I I I$ expression in pancreatic tissue revealed expression restricted to insulin-producing $\beta$ cells (Fig. 1), which was enhanced after pro-inflammatory cytokineinduced stress (Fig. 2).

During the pathogenesis of IDDM, macrophages and $\mathrm{T}$ cells recruited to the islets play an essential role due to their synthesis and secretion of pro-inflammatory cytokines IL1 $\beta$, TNF- $\alpha$ and IFN- $\gamma$ as well as ROS and RNS (Delaney et al. 1997, Eizirik \& Mandrup-Poulsen 2001). It has been previously shown that the experimental upregulation of different antioxidant enzymes in insulin-producing $\beta$ cells protects against cytokine-mediated toxicity through prevention of oxidative damage (Hotta et al. 1998, Azevedo-Martins et al. 2003, Gurgul et al. 2004). To analyze PRX III in this respect, we generated stably transfected rat insulinoma cells over- or under-expressing this mitochondrial enzyme induced by doxycyclin (Fig. 3). The Tet-On-system that was successfully used to control $\operatorname{Prx} I I I$ expression did not influence the viability, but was marginally leaky (Fig. 3). Thus, we cannot fully exclude the possibility that the observed activation of the transfected Prx III constructs in the absence of doxycyclin slightly altered the impact of our analyses (Figs 4 and 7-9). However, we believe these effects to be marginal.

We utilized different stressors and measurements of apoptosis, viability and functionality to demonstrate the protective function and properties of PRX III. We analyzed the effects of individual pro-inflammatory cytokines, a mixture of them, hydrogen peroxide, and the diabetogenic substance STZ. The most impressive effects 
A

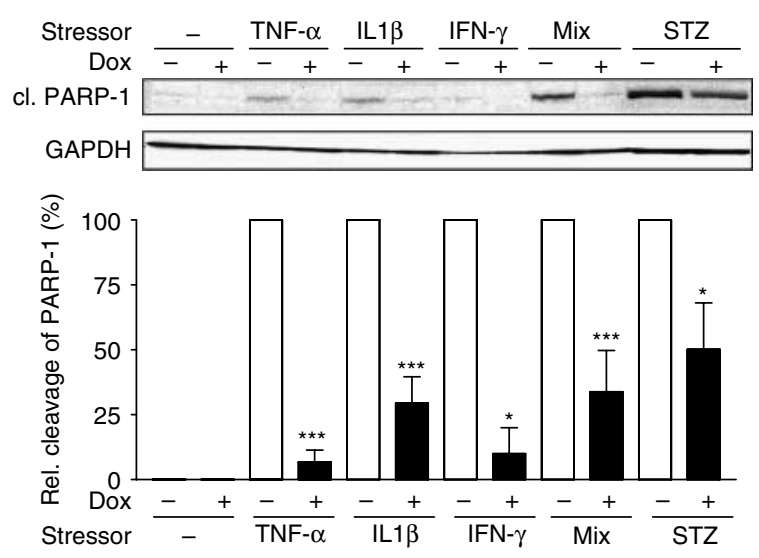

B
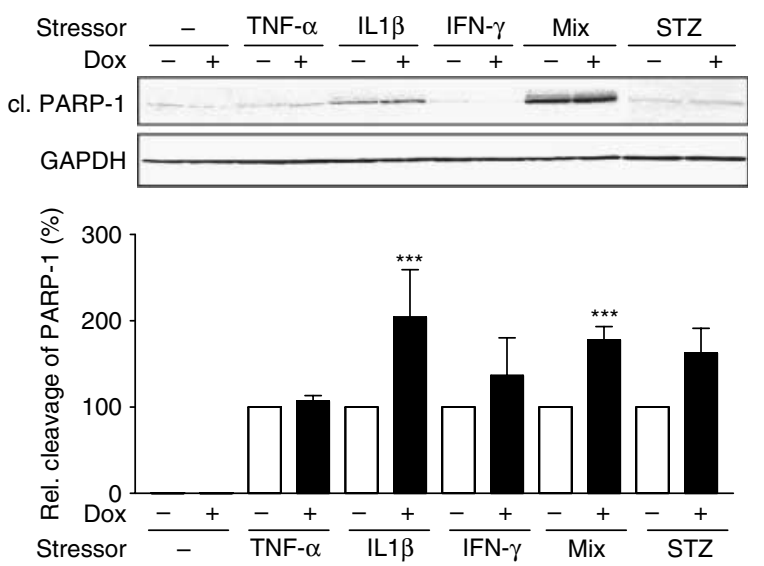

Figure 8 Western blot. Stably transfected RINm5F cells (A) over- or (B) under-expressing Prx III after induction for 4 days with $1 \mu \mathrm{g} / \mathrm{ml}$ doxycyclin (dox) were treated for $24 \mathrm{~h}$ with cytokines $(100 \mathrm{U} / \mathrm{ml}$ TNF- $\alpha, 50 \mathrm{U} / \mathrm{ml} \mathrm{IL} 1 \beta$, and $100 \mathrm{U} / \mathrm{ml} \mathrm{IFN}-\gamma)$ or $4 \mathrm{mmol} / \mathrm{l}$ streptozotocin (STZ). Proteins ( $20 \mu \mathrm{g})$ were subjected to western blot analysis with anti-cleaved PARP-1. The results compared to GAPDH were statistically analyzed $\left(* P<0 \cdot 05,{ }^{* * *} P<0 \cdot 0001\right)$.

were summarized in this article. Only in the cases where the individual cytokines acted differently, we have presented all results obtained (Figs 5 and 7). Similar results were only briefly described.

Oxygen free radicals are potent executors of cell death associated with pro-inflammatory cytokine effects and are known to be involved in $\beta$ cell destruction in type 1 diabetes (Verge et al. 1995, Rabinovitch et al. 1999, Chang et al. 2004). PRX III acts as an effective guardian against excessive oxygen radical generation in mitochondria (Miranda-Vizuete et al. 2000, Nonn et al. 2003, Chang et al. 2004). In our experiments with cells over-expressing PRX III, we were not able to detect a significant accumulation of ROS after stress with $\mathrm{H}_{2} \mathrm{O}_{2}$ or any effect by induction with doxycyclin. This may be due to the leaky Tet-On-system (Fig. 4A). The measurement of viability of the cells under these strong stress conditions revealed that doxycyclin does not provoke cell death per se, and that over-expressing $\operatorname{Pr} x$ III protects from cell death due to exposure to high concentrations of $\mathrm{H}_{2} \mathrm{O}_{2}$ (Fig. 4C and D). Noteworthy are the effects when we transfected with antisense clone, which resulted in a fourfold increase in intracellular reactive oxygen intermediates (Fig. 4B). The same effect was induced by repression of thioredoxin-2, which is used together with thioredoxin reductase-2 for regeneration of PRX III (Tanaka et al. 2002). In addition to increasing oxidative stress, the cytokine IL1 $\beta$ plays a key role in $\mathrm{NO}^{\circ}$-dependent destruction of $\beta$ cells (McDaniel et al. 1996). It induces a broad range of signaling pathways including upregulation of iNOS via nuclear factor 'kappa-light-chain-enhancer' of activated $\beta$-cells $(\mathrm{NF}-\kappa \mathrm{B})$ and signal transducers and activators of transcription (STAT)
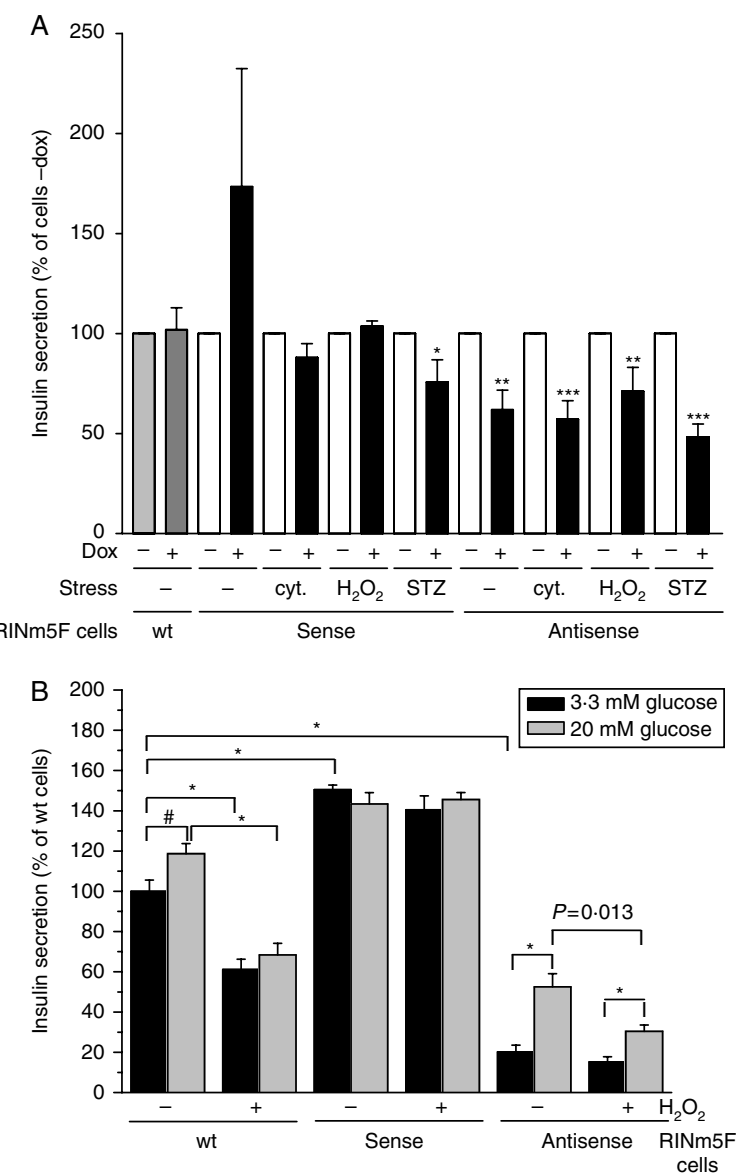

Figure 9 Insulin secretion. (A) Stably transfected cells, expressing the sense or antisense construct, were treated for 4 days with/ without $1 \mu \mathrm{g} / \mathrm{ml}$ doxycyclin (dox). Basal insulin secretion of $24 \mathrm{~h}$ was analyzed in the culture medium using a rat insulin RIA kit (for wild-type - dox $100 \%$ is equivalent to $267.5 \mathrm{ng} / \mathrm{ml}$ ). The samples were counted by a gamma counter for $1 \mathrm{~min}$. (B) Glucosestimulated insulin secretion and its sensitivity to $80 \mu \mathrm{M} \mathrm{H}_{2} \mathrm{O}_{2}$ were determined in wild-type cells as well as in Prx III sense and Prx III antisense cells. The results obtained from at least three independent experiments measured in duplicates were statistically analyzed $\left({ }^{*} P<0 \cdot 01,{ }^{\sharp} P<0 \cdot 05\right.$, and $\left.{ }^{* *} P<0 \cdot 005\right)$. 
activation. Our results indicate that a mitochondrial generation of ROS may further amplify the direct cytokinedependent induction of iNOS, which can be partially suppressed but not prevented by PRX III (Fig. 5). This is in agreement with our previous results of experiments with wild-type cells and different antioxidants (Michalska et al. 2010). In a synergism with the ROS, $\mathrm{NO}^{\circ}$ forms various toxic radicals that modify cellular structures such as lipids, nucleic acids, and proteins, especially iron-containing enzymes of the mitochondrial respiratory chain and Krebs cycle. The resulting production of ROS by the impaired respiratory chain mediates the loss of membrane potential and release of cytochrome $c$. In the cytosol, cytochrome $c$ induces the oligomerization of the apoptotic protease-activating factor 1, which recruits the pro-caspase-9. By this mechanism, the apoptosome is assembled, which leads to autoprocessing of caspase-9, increasing its catalytic activity, which is important for the activation of effector caspase-3 (Adrain \& Martin 2001). We demonstrated that stably transfected RINm5F cells over-expressing the peroxidase PRX III were protected against ROS-induced damaging mechanisms as cell death (Fig. 4), iNOS induction (Fig. 5), loss of mitochondrial membrane potential (Fig. 6), and activation of caspase-9 and -3 (Fig. 7) after stress with proinflammatory cytokines, $\mathrm{H}_{2} \mathrm{O}_{2}$ or STZ. The increased apoptotic signals measured in the antisense clone verified these results. Similar observations were made in HeLa cells suppressing Prx III (Chang et al. 2004) or in WEHI7.2 thymoma cells over-expressing Prx III (Nonn et al. 2003). A further method to analyze apoptosis is the detection of cleaved PARP as a well-known substrate of activated caspase3 (Nargi-Aizenman et al. 2002). We were able to demonstrate that over-expression of $\operatorname{Pr} x$ III significantly suppressed the cleavage of PARP-1, while a downregulation of $\operatorname{Pr} x$ III resulted in an almost twofold increase in the PARP-derived $24 \mathrm{kDa}$ fragment (Fig. 8).

Insulin synthesis and secretion are closely connected to mitochondrial function. The increased ATP level from metabolized glucose represents an important stimulussecretion signal for the function of pancreatic $\beta$ cells (Maechler et al. 1997). Oxidative stress leads to mitochondrial dysfunction and reduced metabolic stimulussecretion coupling. However, probably because of the requirement of small amounts of $\mathrm{H}_{2} \mathrm{O}_{2}$ in normal cell function, it could be critical to express appropriate levels of antioxidant proteins ( $\mathrm{Pi}$ et al. 2007). In Prx III overexpressing cells, insulin secretion was positively affected (Fig. 9), demonstrating that upregulation of $\operatorname{Pr} x I I I$ is not detrimental to $\beta$ cell function. In cells where the expression of $\operatorname{Pr} x I I I$ was suppressed by doxycyclin, insulin secretion was lowered significantly (Fig. 9). However, the price for the protection of $\beta$ cells by antioxidant enzymes could be the loss of glucose sensitivity. Over-expression of Prx III resulted in a high secretion of insulin without further increase after stimulation with glucose (Fig. 9B).
Thus, our work has demonstrated that over-expression of the mitochondrial PRX III can protect against oxidative and nitrosative stress induced by cytokines or chemical generators of oxygen free radicals and $\mathrm{NO}^{\circ}$. Positive features of PRX III have been previously published: e.g. $\operatorname{Prx} I I I$ gene expression is inducible by oxidative stress (Mitsumoto et al. 2001, Lee et al. 2007). Through the interaction of PRX III with leucine zipper-bearing kinase, activation of $\mathrm{NF \kappa B}$ can be modified (Masaki et al. 2003). Furthermore, Prx III was identified as a gene regulated by the transcription factor $\mathrm{c}-\mathrm{Myc}$, which plays an important role in the regulation of the cell cycle, cell proliferation, and differentiation, as well as in apoptosis (Wonsey et al. 2002). It may not be surprising therefore to find high expression levels in tumor cells and several human cancers, where it may protect the growing tumor against hypoxia-induced apoptosis due to increased $\mathrm{H}_{2} \mathrm{O}_{2}$ production (Nonn et al. 2003, Chua et al. 2010). Indeed, in HeLa cells the amount of PRX III is 30-fold higher than glutathione peroxidase (Chang et al. 2004).

Our results are also in line with the recently published data from transgenic PRX III over-expressing mice. Cells from these mice had increased resistance to stress-induced cell death and apoptosis. Interestingly, the mice showed improved glucose homeostasis, as evidenced by their reduced levels of blood glucose and increased glucose clearance. They are also protected against hyperglycemia and glucose intolerance induced by high-fat diet feeding. The results from Chen et al. (2008) further showed that the inhibition of glycogen synthase kinase-3 (GSK3) may play a role in mediating the improved glucose tolerance phenotype and indicate that reduction in mitochondrial $\mathrm{H}_{2} \mathrm{O}_{2}$ by overexpressing PRX III improves glucose tolerance.

So we propose that PRXs could be an attractive target to protect $\beta$ cell function and mass in vivo and thus delay manifestation of IDDM.

\section{Declaration of interest}

The authors declare that there is no conflict of interest that could be perceived as prejudicing the impartiality of the research reported.

\section{Funding}

This work was supported by the foundation 'Das zuckerkranke Kind' of Deutsche Diabetes-Stiftung and by the European Union coordinated action programme (TONECA: EU-6FP-TONECA Contr. No LSHM-CT2004-503245)

\section{References}

Abdel-Rahman MS, Elrakhawy FI \& Iskander FA 1992 Protection of B cells against the effect of alloxan. Toxicology Letters 63 155-164. (doi:10.1016/ 0378-4274(92)90007-7)

Adrain C \& Martin SJ 2001 The mitochondrial apoptosome: a killer unleashed by the cytochrome seas. Trends in Biochemical Sciences 26 390-397. (doi:10.1016/S0968-0004(01)01844-8) 
Araki M, Nanri H, Ejima K, Murasato Y, Fujiwara T, Nakashima Y \& Ikeda M 1999 Antioxidant function of the mitochondrial protein SP-22 in the cardiovascular system. Journal of Biological Chemistry 274 2271-2278. (doi:10.1074/jbc.274.4.2271)

Azevedo-Martins AK, Lortz S, Lenzen S, Curi R, Eizirik DL \& Tiedge M 2003 Improvement of the mitochondrial antioxidant defense status prevents cytokine-induced nuclear factor- $\mathrm{\kappa B}$ activation in insulin-producing cells. Diabetes 52 93-101. (doi:10.2337/diabetes.52.1.93)

Bast A, Wolf G, Oberbäumer I \& Walther R 2002 Oxidative and nitrosative stress induces peroxiredoxins in pancreatic beta cells. Diabetologia $\mathbf{4 5}$ 867-876. (doi:10.1007/s00125-002-0846-1)

Bernabe JC, Tejedo JR, Rincon P, Cahuana GM, Ramirez R, Sobrino F \& Bedoya F 2001 Sodium nitroprusside-induced mitochondrial apoptotic events in insulin-secreting RINm5F cells are associated with MAP kinases activation. Experimental Cell Research 269 222-229. (doi:10.1006/excr.2001.5315)

Chae HZ, Kim HJ, Kang SW \& Rhee SG 1999 Characterization of three isoforms of mammalian peroxiredoxin that reduce peroxides in the presence of thioredoxin. Diabetes Research and Clinical Practice 45 101-112. (doi:10. 1016/S0168-8227(99)00037-6)

Chang TS, Cho CS, Park S, Yu S, Kang SW \& Rhee SG 2004 Peroxiredoxin III, a mitochondrion-specific peroxidase, regulates apoptotic signaling by mitochondria. Journal of Biological Chemistry 279 41975-41984. (doi:10. 1074/jbc.M407707200)

Chen L, Na R, Gu M, Salmon AB, Liu Y, Liang H, Qi W, Van Remmen H, Richardson A \& Ran Q 2008 Reduction of mitochondrial $\mathrm{H}_{2} \mathrm{O}_{2}$ by overexpressing peroxiredoxin 3 improves glucose tolerance in mice. Aging Cell 7 866-878. (doi:10.1111/j.1474-9726.2008.00432.x)

Chua PJ, Lee EH, Yu Y, Yip GW, Tan PH \& Bay BH 2010 Silencing the peroxiredoxin III gene inhibits cell proliferation in breast cancer. International Journal of Oncology 36 359-364. (doi:10.3892/ijo_00000507)

Delaney CA, Paviovic D, Hoorens A, Pipeleers DG \& Eizirik DL 1997 Cytokines induce deoxyribonucleic acid strand breaks and apoptosis in human pancreatic islet cells. Endocrinology 138 2610-2614. (doi:10.1210/ en.138.6.2610)

Eizirik DL \& Mandrup-Poulsen T 2001 A choice of death - the signal-transduction of immune-mediated beta-cell apoptosis. Diabetologia 44 2115-2133. (doi:10.1007/s001250100021)

Gandy SE, Buse MG \& Crouch RK 1982 Protective role of superoxide dismutase against diabetogenic drugs. Journal of Clinical Investigation $\mathbf{7 0}$ 650-658. (doi:10.1172/JCI110659)

Grankvist K, Marklund SL \& Täljedal IB 1981 CuZn-superoxide dismutase, $\mathrm{Mn}$-superoxide dismutase, catalase and glutathione peroxidase in pancreatic islets and other tissues in the mouse. Biochemical Journal 199 393-398.

Gurgul E, Lortz S, Tiedge M, Jörns A \& Lenzen S 2004 Mitochondrial catalase overexpression protects insulin-producing cells against toxicity of reactive oxygen species and proinflammatory cytokines. Diabetes $\mathbf{5 3}$ 2271-2280. (doi:10.2337/diabetes.53.9.2271)

Harmon JS, Bogdani M, Parazzoli SD, Mak SS, Oseid EA, Berghmans M, Leboeuf RC \& Robertson RP 2009 $\beta$-Cell-specific overexpression of glutathione peroxidase preserves intranuclear MafA and reverses diabetes in db/db mice. Endocrinology 150 4855-4862. (doi:10.1210/en. 2009-0708)

Hattori F, Murayama N, Noshita T \& Oikawa S 2003 Mitochondrial peroxiredoxin-3 protects hippocampal neurons from excitotoxic injury in vivo. Journal of Neurochemistry 86 860-868. (doi:10.1046/j.1471-4159. 2003.01918.x)

Hotta M, Tashiro F, Ikegami H, Niwa H, Ogihara T, Yodoi J \& Miyazaki J 1998 Pancreatic beta cell-specific expression of thioredoxin, an antioxidative and antiapoptotic protein, prevents autoimmune and streptozotocin-induced diabetes. Journal of Experimental Medicine 188 1445-1451. (doi:10.1084/jem.188.8.1445)

Kang SW, Rhee SG, Chang TS, Jeong W \& Choi MH 2005 2-Cys peroxiredoxin function in intracellular signal transduction: therapeutic implications. Trends in Molecular Medicine 11 571-578. (doi:10.1016/ j.molmed.2005.10.006)
Kiely A, McClenaghan NH, Flatt PF \& Newsholme P 2007 Pro-inflammatory cytokines increase glucose, alanine and triacylglycerol utilization but inhibit insulin secretion in a clonal pancreatic beta-cell line. Journal of Endocrinology 195 113-123. (doi:10.1677/JOE-07-0306)

Knopp E, Arndt TL, Eng KL, Caldwell M, LeBoeuf RC, Deeb SS \& O'Brien KD 1999 Murine phospholipid hydroperoxide glutathione peroxidase: cDNA sequence, tissue expression, and mapping. Mammalian Genome 10 601-605. (doi:10.1007/s003359901053)

L'Abbe MR \& Trick KD 1994 Changes in pancreatic glutathione peroxidase and superoxide dismutase activities in the prediabetic diabetes-prone BB rat. Proceedings of the Society for Experimental Biology and Medicine 207 206-121.

Lee W, Wells T \& Kantorow M 2007 Localization and $\mathrm{H}_{2} \mathrm{O}_{2}$-specific induction of PRDX3 in the eye lens. Molecular Vision 13 1469-1474.

Lenzen S, Drinkgern J \& Tiedge M 1996 Low antioxidant enzyme gene expression in pancreatic islets compared with various other mouse tissues. Free Radical Biology and Medicine 20 463-466. (doi:10.1016/08915849(96)02051-5)

Li X, Chen H \& Epstein PN 2006 Metallothionein and catalase sensitize to diabetes in nonobese diabetic mice: reactive oxygen species may have a protective role in pancreatic beta-cells. Diabetes 55 1592-1604. (doi:10.2337/db05-1357)

Lottmann H, Vanselow J, Hessabi B \& Walther R 2001 The Tet-On system in transgenic mice: inhibition of the mouse pdx-1 gene activity by antisense RNA expression in pancreatic beta-cells. Journal of Molecular Medicine 79 321-328. (doi:10.1007/s001090100229)

Maechler P, Kennedy ED, Pozzan T \& Wollheim CB 1997 Mitochondrial activation directly triggers the exocytosis of insulin in permeabilized pancreatic beta-cells. EMBO Journal 16 3833-3841. (doi:10.1093/emboj/ 16.13.3833)

Mandrup-Poulsen T, Helqvist S, Wogensen LD, Molvig J, Pociot F, Johannesen J \& Nerup J 1990 Cytokine and free radicals as effector molecules in the destruction of pancreatic beta cells. Current Topics in Microbiology and Immunology 164 169-193.

Masaki M, Ikeda A, Shiraki E, Oka S \& Kawasaki T 2003 Mixed lineage kinase LZK and antioxidant protein-1 activate NF- $\mathrm{\kappa B}$ synergistically. European Journal of Biochemistry 270 76-83. (doi:10.1046/j.1432-1033.2003. 03363.x)

Maxwell SR, Thomason H, Sandler D, Leguen C, Baxter MA, Thorpe GH, Jones AF \& Barnett AH 1997 Antioxidant status in patients with uncomplicated insulin-dependent and non-insulin-dependent diabetes mellitus. European Journal of Clinical Investigation 27 484-490. (doi:10.1046/ j.1365-2362.1997.1390687.x)

McDaniel ML, Kwon G, Hill JR, Marshall CA \& Corbett JA 1996 Cytokines and nitric oxide in islet inflammation and diabetes. Proceedings of the Society for Experimental Biology and Medicine 211 24-32.

Michalska M, Wolf G, Walther R \& Newsholme P 2010 The effects of pharmacologic inhibition of NADPH oxidase or iNOS on proinflammatory cytokine, palmitic acid or $\mathrm{H}_{2} \mathrm{O}_{2}$-induced mouse islet or clonal pancreatic beta cell dysfunction. Bioscience Reports 30 445-453. (doi:10.1042/BSR 20090138)

Miranda-Vizuete A, Damdimopoulos AE \& Spyrou G 2000 The mitochondrial thioredoxin system. Antioxidants \& Redox Signaling 2 801-810. (doi:10.1089/ars.2000.2.4-801)

Mitsumoto A, Takanezawa Y, Okawa K, Iwamatsu A \& Nakagawa Y 2001 Variants of peroxiredoxins expression in response to hydroperoxide stress. Free Radical Biology and Medicine 30 625-635. (doi:10.1016/S08915849(00)00503-7)

Nargi-Aizenman JL, Simbulan-Rosenthal CM, Kelly TA, Smulson ME \& Griffin DE 2002 Rapid activation of poly(ADP-ribose) polymerase contributes to Sindbis virus and staurosporine-induced apoptotic cell death. Virology 293 164-171. (doi:10.1006/viro.2001.1253)

Nonn L, Berggren M \& Powis G 2003 Increased expression of mitochondrial peroxiredoxin-3 (thioredoxin peroxidase-2) protects cancer cells against hypoxia and drug-induced hydrogen peroxide-dependent apoptosis. Molecular Cancer Research 1 682-689.

Petrosillo G, Ruggiero FM \& Paradies G 2003 Role of reactive oxygen species and cardiolipin in the release of cytochrome $c$ from mitochondria. FASEB Journal 17 2202-2208. (doi:10.1096/fj.03-0012com) 
Pi J, Bai Y, Zhang Q, Wong V, Floering LM, Daniel K, Reece JM, Deeney JT, Andersen ME, Corkey BE et al. 2007 Reactive oxygen species as a signal in glucose-stimulated insulin secretion. Diabetes 56 1783-1791. (doi:10.2337/ $\mathrm{db} 06-1601)$

Rabinovitch A \& Suarez-Pinzon WL 1998 Cytokines and their roles in pancreatic islet beta-cell destruction and insulin-dependent diabetes mellitus. Biochemical Pharmacology 55 1139-1149. (doi:10.1016/S00062952(97)00492-9)

Rabinovitch A, Suarez-Pinzon W, Strynadka K, Ju Q, Edelstein D, Brownlee M, Korbutt GS \& Rajotte RV 1999 Transfection of human pancreatic islets with an anti-apoptotic gene (bcl-2) protects beta-cells from cytokine-induced destruction. Diabetes 48 1223-1229. (doi:10.2337/diabetes.48.6.1223)

Radi R, Turrens JF, Chang LY, Bush KM, Crapo JD \& Freeman BA 1991 Detection of catalase in rat heart mitochondria. Journal of Biological Chemistry 266 22028-22034.

Sandstrom J, Jonsson LM, Edlund H, Holmberg D \& Marklund SL 2002 Overexpression of extracellular-SOD in islets of nonobese diabetic mice and development of diabetes. Free Radical Biology and Medicine 33 71-75. (doi:10.1016/S0891-5849(02)00859-6)

Storling J, Binzer J, Andersson AK, Zullig RA, Tonnesen M, Lehmann R, Spinas GA, Sandler S, Billestrup N \& Mandrup-Poulsen T 2005 Nitric oxide contributes to cytokine-induced apoptosis in pancreatic beta cells via potentiation of JNK activity and inhibition of Akt. Diabetologia 48 2039-2050. (doi:10.1007/s00125-005-1912-2)

Suarez-Pinzon WL, Mabley JG, Strynadka K, Power RF, Szabo C \& Rabinovitch A 2001 An inhibitor of inducible nitric oxide synthase and scavenger of peroxynitrite prevents diabetes development in NOD mice. Journal of Autoimmunity 16 449-455. (doi:10.1006/jaut.2001. 0507)

Tanaka T, Hosoi F, Yamaguchi-Iwai Y, Nakamura H, Masutani H, Ueda S, Nishiyama A, Takeda S, Wada H, Spyrou G et al. 2002
Thioredoxin-2 (TRX-2) is an essential gene regulating mitochondriadependent apoptosis. EMBO Journal 21 1695-1703. (doi:10.1093/ emboj/21.7.1695)

Tiedge M, Lortz S, Drinkgern J \& Lenzen S 1997 Relation between antioxidant enzyme gene expression and antioxidative defense status of insulin-producing cells. Diabetes 46 1733-1742. (doi:10.2337/diabetes.46. 11.1733)

Verge CF, Gianani R, Yu L, Pietropaolo M, Smith T, Jackson RA, Soeldner JS \& Eisenbarth GS 1995 Late progression to diabetes and evidence for chronic beta-cell autoimmunity in identical twins of patients with type I diabetes. Diabetes 44 1176-1179. (doi:10.2337/ diabetes.44.10.1176)

Watabe S, Hiroi T, Yamamoto Y, Fujioka Y, Hasegawa H, Yago N \& Takahashi SY 1997 SP-22 is a thioredoxin-dependent peroxide reductase in mitochondria. European Journal of Biochemistry 249 52-60. (doi:10.1111/ j.1432-1033.1997.t01-1-00052.x)

Wonsey DR, Zeller KI \& Dang CV 2002 The c-Myc target gene PRDX3 is required for mitochondrial homeostasis and neoplastic transformation. PNAS 99 6649-6654. (doi:10.1073/pnas.102523299)

Wood ZA, Schroder E, Robin Harris J \& Poole LB 2003 Structure, mechanism and regulation of peroxiredoxins. Trends in Biochemical Sciences 28 32-40. (doi:10.1016/S0968-0004(02)00003-8)

Yamamoto T, Matsui Y, Natori S \& Obinata M 1989 Cloning of a housekeepingtype gene (MER5) preferentially expressed in murine erythroleukemia cells. Gene 80 337-343. (doi:10.1016/0378-1119(89)90297-7)

Received in final form 29 July 2010

Accepted 31 August 2010

Made available online as an Accepted Preprint 31 August 2010 